\title{
Books to review, by topic: Part II
}

This is Part II of a three-part list of books by topic that we would like reviewed. If you would like to review one of these books, please submit a request to the book review editor, Thomas $M$. Bender, M.D., atlq@cathmed.org.

\section{Catholic Issues}

\section{Catholic Health Care}

Nelson, Leonard J. III. Diagnosis Critical: The Urgent Threats Confronting Catholic Health Care. Huntington, IN: Our Sunday Visitor, Inc., 2009. 304 pp.

Southwell, Darlene. Caring and Compassion: A History of the Sisters of St. Ann in Health Care in British Columbia. Madeira Park, BC, Canada: Harbour Publishing Co., Ltd., 2011. 296 pp.

\section{Catholic Issues}

Francis, Pope. The Name of God Is Mercy, trans. Oonagh Stransky. New York: Random House, 2016. 176 pp.

Hahn, Scott. Signs of Life: 40 Catholic Customs and Their Biblical Roots. New York: Doubleday, 2009. 288 pp. Hart, Mark. Behold the Mystery: A Deeper Understanding of the Catholic Mass. Frederick, MD: The Word Among Us Press, 2014. 186 pp.

Healy, Mary. Healing: Bringing the Gift of God's Mercy to the World. Huntington, IN: Our Sunday Visitor, Inc., 2015. 208 pp.

Hitchcock, James. History of the Catholic Church: From the Apostolic Age to the Third Millennium. San Francisco: Ignatius Press, 2012. 584 pp.
Kaczor, Christopher. The Seven Big Myths about the Catholic Church. San Francisco: Ignatius Press, 2012. 170 pp.

\section{Catholic Moral Theology}

Lawler, Michael G., and Todd A. Salzman. Catholic Theological Ethics: Ancient Questions, Contemporary Responses. Lanham, MD: University Press of America, Inc., 2016. 274 pp.

Mattison, William C. III. Introducing Moral Theology: True Happiness and the Virtues. Grand Rapids, MI: Brazos Press, 2008. 432 pp.

\section{Exorcism and Possession}

Driscoll, Mike. Demons, Deliverance, and Discernment: Separating Fact from Fiction about the Spirit World. El Cajon, CA: Catholic Answers Press, 2015. 199 pp.

Kiely, David, and Christina McKenna. The Dark Sacrament: True Stories of ModernDay Demon Possession and Exorcism. New York: HarperOne, 2007. 432 pp.

\section{Pope John Paul II}

John Paul II, Pope. John Paul II: The Encyclicals in Everyday Language, Definitive Edition of all Fourteen Encyclicals, $3^{\text {rd }}$ ed. Edited by Joseph G. Donders. Maryknoll, NY: Orbis Books, 2005. 401 pp. 
Mathews, Pia. Pope John Paul II and the Apparently "Non-acting" Person. Leominster, Herefordshire, UK: Gracewing Publishing, 2013. 316 pp.

Redzioch, Wlodzimierz. Stories about Saint John Paul II: Told by His Close Friends and Co-Workers. San Francisco: Ignatius Press, 2015. 209 pp.

Schreck, Alan. The Legacy of Pope John Paul II: The Central Teaching of His 14 Encyclicals. Steubenville, OH: Emmaus Road Publishing, 2012. 174 pp.

Spinello, Richard A. Understanding Love and Responsibility: A Companion to Karol Wojtyta's Classic Work. Boston: Pauline Books and Media, 2014. 208 pp.

Spinello, Richard A. The Encyclicals of John Paul II: An Introduction and Commentary. Lanham, MD: Sheed \& Ward, 2012. $266 \mathrm{pp}$.

Spinello, Richard A. The Genius of John Paul II: The Great Pope's Moral Wisdom. Lanham, MD: Sheed \& Ward, 2007. 224 pp.

\section{Saints/Miracles}

Hronas, Georgia. The Holy Unmercenary Doctors: The Saints Anargyroi, Physicians, and Healers of the Orthodox Church. Edina, MN: Light and Life Publishing, 2009. 107 pp.

Molla, Pietro, and Elio Guerriero. Saint Gianna Molla: Wife, Mother, Doctor, trans. James G. Colbert. San Francisco: Ignatius Press, 2004. 155 pp.

Schultz, Nancy Lusignan. Mrs. Mattingly's Miracle: The Prince, the Widow, and the Cure that Shocked Washington City. New Haven, CT: Yale University Press, 2011. 288 pp.

\section{Medical Ethics}

\section{Aquinas and Issues in Medical Ethics}

Eberl, Jason T. Thomistic Principles and Bioethics. New York: Routledge, 2006. 176 pp.
Payne, Craig. Aquinas and Bioethics: Contemporary Issues in the Light of Medieval Thought. Ottumwa, IA: Vision Publishing, 2014. 274 pp.

\section{Bioethics}

Hogan, Margaret Monahan, and David Solomon, eds. Medical Ethics at Notre Dame: The J. Philip Clarke Family Lectures 1988-1999. North Charleston, SC: BookSurge Publishing, 2007. 394 pp.

Jonsen, Albert, Mark Siegler, and William Winslade. Clinical Ethics: A Practical Approach to Ethical Decisions in Clinical Medicine, $8^{\text {th }}$ ed. New York: McGrawHill Education, 2015. 240 pp.

Kaczor, Christopher. The Edge of Life: Human Dignity and Contemporary Bioethics. New York: Springer, 2005. 155 pp.

Kaldjian, Lauris Christopher. Practicing Medicine and Ethics: Integrating Wisdom, Conscience, and Goals of Care. New York: Cambridge University Press, 2014. 296 pp.

Keown, John. The Law and Ethics of Medicine: Essays on the Inviolability of Human Life. New York: Oxford University Press, 2012. 352 pp.

Koch, Tom. Thieves of Virtue: When Bioethics Stole Medicine. Cambridge, MA: Massachusetts Institute of Technology Press, 2012. 376 pp.

Kuhse, Helga, Udo Schüklenk, and Peter Singer, eds. Bioethics: An Anthology, $3^{\text {rd }}$ ed. Malden, MA: Wiley-Blackwell, 2016. 800 pp.

Lerner, Barron H. The Good Doctor: A Father, a Son, and the Evolution of Medical Ethics. Boston: Beacon Press, 2015. 240 pp.

Lizza, John P., ed. Potentiality: Metaphysical and Bioethical Dimensions. Baltimore: Johns Hopkins University Press, 2014. 288 pp.

Lo, Bernard. Resolving Ethical Dilemmas: $A$ Guide for Clinicians, $5^{\text {th }}$ ed. 
Philadelphia: Lippincott Williams \& Wilkins, 2013. 384 pp.

Marcum, James A. The Virtuous Physician: The Role of Virtue in Medicine. New York: Springer, 2012. 242 pp.

\section{Bioethics and Law}

Furrow, Barry, Thomas Greaney, Sandra Johnson, Timothy Jost, and Robert Schwartz. Bioethics: Health Care Law and Ethics, $7^{\text {th }}$ ed. St. Paul, MN: West Academic Publishing, 2013. 624 pp.

Griffiths, Danielle, and Andrew Sanders, eds. Bioethics, Medicine and the Criminal Law, vol. 2, Medicine, Crime, and Society. New York: Cambridge University Press, 2013. $351 \mathrm{pp}$.

Hakim, Nadey, Vassilios Papalois, and Miran Epstein, eds. Ethical and Legal Issues in Modern Surgery. Hackensack, NJ: World Scientific Publishing Company, 2015. $500 \mathrm{pp}$.

\section{Catholic Health Care Ethics}

Kaczor, Christopher. The Edge of Life: Human Dignity and Contemporary Bioethics. New York: Springer, 2005. 155 pp.

Kane, Brian. The Blessing of Life: An Introduction to Catholic Bioethics. Lanham, MD: Lexington Books, 2011. 172 pp.

Kelly, David F. Medical Care at the End of Life: A Catholic Perspective. Washington, DC: Georgetown University Press, 2006. 192 pp.

Kelly, David F., Gerard Magill, and Henk Ten Have. Contemporary Catholic Health Care Ethics, $2^{\text {nd }}$ ed. Washington, D.C.: Georgetown University Press, 2013. 288 pp.

Lysaught, M. Therese, Joseph Kotva, Stephen E. Lammers, and Allen Verhey, eds. On Moral Medicine: Theological Perspectives on Medical Ethics, $3^{\text {rd }}$ ed. Grand Rapids, MI: William B. Eerdmans Publishing Co., 2012. 1180 pp.
Mazur, Grzegorz. Informed Consent, Proxy Consent, and Catholic Bioethics: For the Good of the Subject. New York: Springer, 2012. 244 pp.

McMahon, Kevin T., ed. Moral Issues in Catholic Health Care. Philadelphia: Saint Charles Borromeo Seminary, 2004. 182 pp.

Miravalle, John-Mark. The Drug, the Soul, E God: A Catholic Moral Perspective on Antidepressants. Scranton, PA: University of Scranton Press, 2010. 150 pp.

Morris, John F., ed. Medicine, Health Care, and Ethics: Catholic Voices. Washington, D.C.: The Catholic University of America Press, 2007. 371 pp.

\section{Christian Bioethics}

Meilaender, Gilbert. Bioethics: A Primer for Christians, $3^{\text {rd }}$ ed. Grand Rapids, MI: William B. Eerdmans Publishing Co., 2012. 152 pp.

Mitchell, C. Ben, and D. Joy Riley. Christian Bioethics: A Guide for Pastors, Health Care Professionals, and Families. Nashville, TN: B\&H Publishing Group, 2014. 224 pp.

\section{Conscience}

Lynch, Holly Fernandez. Conflicts of Conscience in Health Care: An Institutional Compromise. Cambridge, MA: Massachusetts Institute of Technology Press, 2008. 368 pp.

\section{Global Health Care}

Fox, Renée C. Doctors Without Borders: Humanitarian Quests, Impossible Dreams of Médecins Sans Frontières. Baltimore: Johns Hopkins University Press, 2014. 328 pp.

Jacobsen, Kathryn H. Introduction to Global Health, $2^{\text {nd }}$ ed. Burlington, MA: Jones \& Bartlett Learning, 2014. 404 pp. 


\section{Healthcare Ethics Committees}

Hester, D. Micah, and Toby Schonfeld, eds. Guidance for Healthcare Ethics Committees. New York: Cambridge University Press, 2012. 196 pp.

\section{Hippocratic Oath and Hippocratic Medicine}

Jones, W.H.S. The Doctor's Oath: An Essay in the History of Medicine. New York: Cambridge University Press, 1924, reprint 2013. $72 \mathrm{pp}$.

\section{History of Bioethics}

Ferber, Sarah. Bioethics in Historical Perspective. New York: Palgrave Macmillan, 2013. 248 pp.

\section{Human Dignity}

Dilley, Stephen, and Nathan J. Palpant, eds. Human Dignity in Bioethics: From Worldviews to the Public Square. New York: Routledge, 2013. 396 pp.

Kaczor, Christopher. The Edge of Life: Human Dignity and Contemporary Bioethics. New York: Springer, 2005. 155 pp.

\section{Methods in Medical Ethics}

Sugarman, Jeremy, and Daniel P. Sulmasy, eds. Methods in Medical Ethics, $2^{\text {nd }}$ ed. Washington, DC: Georgetown University Press, 2010. 344 pp.

\section{Military Medical Ethics}

Gross, Michael L. Bioethics and Armed Confict: Moral Dilemmas of Medicine and War. Cambridge, MA: Massachusetts Institute of Technology Press, 2006. 400 pp.

\section{Philosophy of Medicine}

Mallia, Pierre. The Nature of the DoctorPatient Relationship: Health Care Principles Through the Phenomenology of Relationships with Patients. New York: Springer, 2013. 86 pp.

Marcum, James A. An Introductory Philosophy of Medicine: Humanizing Modern Medicine. New York: Springer, 2008. 376 pp.

Pellegrino, Edmund. The Philosophy of Medicine Reborn: A Pellegrino Reader. $\mathrm{H}$. Tristram Englehardt Jr., and Fabrice Jotterand, eds. Notre Dame, IN: University of Notre Dame Press, 2008. 472 pp.

\section{Common Good \\ Health Policy}

Burnham, John C. Health Care in America: A History. Baltimore: Johns Hopkins University Press, 2015. 616 pp.

\section{Public Health}

Jennings, Bruce, John D. Arras, Drue H. Barrett, and Barbara A. Ellis, eds. Emergency Ethics: Public Health Preparedness and Response. New York: Oxford University Press, 2016. 320 pp.

O’Mathúna, Dónal P., Bert Gordijn, and Mike Clarke, eds. Disaster Bioethics: Normative Issues When Nothing Is Normal. New York: Springer, 2014. 228 pp.

\section{Health Care Professionals}

\section{Biographies}

Jacobs, Charlotte DeCroes. Jonas Salk: $A$ Life. New York: Oxford University Press, 2015. 559 pp.

Joffe, Stephen N. Andreas Vesalius: The Making, the Madman, and the Myth. Bloomington, IN: AuthorHouse, 2014. $210 \mathrm{pp}$. 
Lejeune-Gaymard, Clara. Life Is a Blessing: A Biography of Jérôme Lejeune: Geneticist, Doctor, Father, trans. Michael Miller. Philadelphia: The National Catholic Bioethics Center, 2010. 149 pp.

\section{Health Administration and Management}

Morrison, Eileen E. Ethics in Health Administration: A Practical Approach for Decision Makers, $3^{\text {rd }}$ ed. Burlington, MA: Jones \& Bartlett Learning, 2015. 406 pp.

\section{Nursing}

Grace, Pamela. Nursing Ethics and Professional Responsibility in Advanced Practice, $2^{\text {nd }}$ ed. Burlington, MA: Jones \& Bartlett Learning, 2014. 560 pp.

\section{Physician Assistant}

Cassidy, Barry, and J, Dennis Blessing. Ethics and Professionalism: A Guide for the Physician Assistant. Philadelphia: F. A. Davis Company, 2008. 256 pp.

\section{Physicians}

Marcum, James A. The Virtuous Physician: The Role of Virtue in Medicine. New York: Springer, 2012. 242 pp.

McClelland, Charles E. Queen of the Professions: The Rise and Decline of Medical Prestige and Power in America. Lanham, MD: Rowman \& Littlefield Publishers, 2014. 214 pp.

Mohr, James C. Licensed to Practice: The Supreme Court Defines the American Medical Profession. Baltimore: Johns Hopkins University Press, 2013. 224 pp.

\section{IssuEs}

\section{Margaret Sanger}

Sanger, Margaret. The Selected Papers of Margaret Sanger, vol. 1, The Woman Rebel. Chicago: University of Illinois Press, 2003. 576 pp.

\section{Marriage and Family}

Hanley, Matthew, and Jokin de Irala. Affirming Love, Avoiding AIDS: What Africa Can Teach the West. Philadelphia: The National Catholic Bioethics Center, 2009. 202 pp.

Kaczor, Christopher, and Jennifer Kaczor. The Seven Big Myths about Marriage. San Francisco: Ignatius Press, 2014. 207 pp.

Lee, Patrick, and Robert P. George. Conjugal Union: What Marriage Is and Why It Matters. New York: Cambridge University Press, 2014. 152 pp.

May, William E. Marriage: The Rock on Which the Family Is Built, revised and expanded ed. San Francisco: Ignatius Press, 2009. 198 pp.

\section{Nazi Medical Crimes}

Binding, Karl, and Alfred Hoche. Allowing the Destruction of Life Unworthy of Life: Its Measure and Form, trans. Cristina Modak. Greenwood, WI: Suzeteo Enterprises, 2015. 120 pp.

Evans, Susanne E. Forgotten Crimes: The Holocaust and People with Disabilities. Chicago: Ivan R. Dee, Publisher, 2004. $224 \mathrm{pp}$.

\section{Beginning of Life}

\section{Abortion}

Forsythe, Clarke D. Abuse of Discretion: The Inside Story of Roe v. Wade. New York: Encounter Books, 2013. 496 pp. 
Johnson, Abby, and Kristin Detrow. The Walls Are Talking: Former Abortion Clinic Workers Tell Their Stories. San Francisco: Ignatius Press, 2016. 160 pp.

Johnson, Abby, and Cindy Lambert. Unplanned: The Dramatic True Story of a Former Planned Parenthood Leader's Eye-Opening Journey Across the Life Line. Carol Stream, IL: Tyndale House Publishers, Inc., 2011. 288 pp.

Kaczor, Christopher. The Ethics of Abortion: Women's Rights, Human Life, and the Question of Justice. New York: Routledge, 2010. 256 pp.

Lee, Patrick. Abortion \& Unborn Human Life, $2^{\text {nd }}$ ed. Washington, DC: The Catholic University of America Press, 2010. 177 pp.

McElhinney, Ann, and Phelim McAleer. Gosnell: The Story of America's Most Prolific Serial Killer. Washington, DC: Regnery Publishing, 2016. 256 pp.

\section{Embryos}

Brakman, Sarah-Vaughan, and Darlene Fozard Weaver, eds. The Ethics of Embryo Adoption and the Catholic Tradition: Moral Arguments, Economic Reality and Social Analysis. New York: Springer, 2007. 326 pp.

Østnor, Lars. Stem Cells, Human Embryos and Ethics: Interdisciplinary Perspectives. New York: Springer, 2008. 255 pp.

\section{Neonatology}

Bhatia, Neera. Critically Impaired Infants and End of Life Decision Making: Resource Allocation and Difficult Decisions. New York: Routledge, 2015. 246 pp.

Camosy, Charles C. Too Expensive to Treat? Finitude, Tragedy, and the Neonatal ICU. Grand Rapids, MI: William B. Eerdmans Publishing Co., 2010. 242 pp.
Clark, Peter A. To Treat or Not to Treat: The Ethical Methodology of Richard A. McCormick, S.J., as Applied to Treatment Decisions for Handicapped Newborns. New York: Fordham University Press, 2003. 349 pp.

Lantos, John, and Diane S. Lauderdale. Preterm Babies, Fetal Patients, and Childbearing Choices. Cambridge, MA: Massachusetts Institute of Technology Press, 2015. 232 pp.

\section{Pro-Life}

Alcorn, Randy C. Why Pro-Life?: Caring for the Unborn and Their Mothers, rev. ed. Peabody, MA: Hendrickson Publishers Marketing, LLC, 2012. 172 pp.

Beckwith, Francis J. Defending Life: $A$ Moral and Legal Case Against Abortion Choice. New York: Cambridge University Press, 2007. 314 pp.

Horn, Trent. Persuasive Pro-Life: How to Talk about Our Culture's Toughest Issue. El Cajon, CA: Catholic Answers Press, 2014. 335 pp.

\section{Stem Cell Research}

Buratovich, Michael A. The Stem Cell Epistles: Letters to My Students about Bioethics, Embryos, Stem Cells, and Fertility Treatments. Eugene, OR: Cascade Books, 2013. 274 pp.

Hyun, Insoo. Bioethics and the Future of Stem Cell Research. New York: Cambridge University Press, 2013. 239 pp.

\section{Sexual Ethics}

\section{Contraception and the Sexual Revolution}

Eberstadt, Mary. Adam and Eve after the Pill: Paradoxes of the Sexual Revolution. San Francisco: Ignatius Press, 2012. $175 \mathrm{pp}$. 
Eig, Jonathan. The Birth of the Pill: How Four Crusaders Reinvented Sex and Launched a Revolution. New York: W.W. Norton \& Company, 2014. $400 \mathrm{pp}$.

Engelman, Peter C. A History of the Birth Control Movement in America. Santa Barbara, CA: Praeger, 2011. 231 pp.

Franks, Angela. Contraception and Catholicism: What the Church Teaches and Why. Boston: Pauline Books and Media, 2013. $122 \mathrm{pp}$.

\section{Infertility}

Dimech-Juchniewicz, Jean. Facing Infertility: A Catholic Approach. Boston: Pauline Books and Media, 2012. 192 pp.

\section{LGBT}

Cameli, Louis J. Catholic Teaching on Homosexuality: New Paths to Understanding. Notre Dame, IN: Ave Maria Press, 2012. 192 pp.

Feder, Ellen K. Making Sense of Intersex: Changing Ethical Perspectives in Biomedicine. Bloomington, IN: Indiana University Press, 2014. 278 pp.

\section{Sexual Ethics}

Bachiochi, Erika, ed. Women, Sex, and the Church: A Case for Catholic Teaching. Boston: Pauline Books \& Media, 2010. $251 \mathrm{pp}$.

Grabowski, John S. Sex and Virtue: An Introduction to Sexual Etbics. Washington, D.C.: The Catholic University of America Press, 2003. 197 pp.

Grossman, Miriam. You're Teaching My Child What?: A Physician Exposes the Lies of Sex Ed and How They Harm Your Child. Washington, DC: Regnery Publishing, Inc., 2009. 256 pp.

\section{Areas of EXPERTISE}

\section{Anesthesiology}

Jericho, Barbara G. Ethical Issues in Anesthesiology and Surgery. New York: Springer, 2015. 238 pp.

\section{Biomedical Research}

Coleman, Carl H., Jerry A. Menikoff, Jesse A. Goldner, and Efthimios Parasidis. The Ethics and Regulation of Research with Human Subjects, $2^{\text {nd }}$ ed. New York: LexisNexis, 2015. 1030 pp.

D'Angelo, John. Ethics in Science: Ethical Misconduct in Scientific Research. Boca Raton, FL: CRC Press, 2012. 130 pp.

Emanuel, Ezekiel J., Christine C. Grady, Robert A. Crouch, Reidar K. Lie, Franklin G. Miller, and David D. Wendler, eds. The Oxford Textbook of Clinical Research Ethics. New York: Oxford University Press, 2008. 848 pp.

Lo, Bernard. Ethical Issues in Clinical Research: A Practical Guide. Philadelphia: Lippincott Williams \& Wilkins, 2010. 300 pp.

\section{Disabilities}

Barnbaum, Deborah R. The Ethics of Autism: Among Them, But Not of Them. Bloomington, IN: Indiana University Press, 2008. 233 pp.

Bock, Brian, and John Swinton, eds. Disability in the Christian Tradition: A Reader. Grand Rapids, MI: William B. Eerdmans Publishing Co., 2012. $576 \mathrm{pp}$.

\section{Eugenics}

Bashford, Allison, and Philippa Levine, eds. The Oxford Handbook of the History of Eugenics. New York: Oxford University Press, 2010. 608 pp. 
Binding, Karl, and Alfred Hoche. Allowing the Destruction of Life Unworthy of Life: Its Measure and Form, trans. Cristina Modak. Greenwood, WI: Suzeteo Enterprises, 2015. 120 pp.

Black, Edwin. War Against the Weak: Eugenics and America's Campaign to Create a Master Race, rev. ed. Washington, DC: Dialog Press, 2012. 608 pp.

Franks, Angela. Margaret Sanger's Eugenic Legacy: The Control of Female Fertility. Jefferson, NC: McFarland \& Company, Inc., 2005. 352 pp.

\section{Genetics and Genetic Engineering}

Bayefsky, Michelle, and Bruce Jennings. Regulating Preimplantation Genetic Diagnosis in the United States: The Limits of Unlimited Selection. New York: Palgrave Macmillan, 2015. 124 pp.

Berliner, Janice, ed. Ethical Dilemmas in Genetics and Genetic Counseling: Principles through Case Scenarios. New York: Oxford University Press, 2015. 240 pp.

Berry, Roberta M. The Ethics of Genetic Engineering. New York: Routledge, 2007. 240 pp.

\section{Microbes, Viruses, and Plagues}

Aberth, John. Plagues in World History. Lanham, MD: Rowman \& Littlefield Publishers, 2011. 256 pp.

Blaser, Martin J. Missing Microbes: How the Overuse of Antibiotics Is Fueling Our Modern Plagues. New York: Henry Holt and Company, 2014. 288 pp.

Crawford, Dorothy H. Deadly Companions: How Microbes Shaped Our History. New York: Oxford University Press, 2007. 272 pp.

Hardt, Mark D. History of Infectious Disease Pandemics in Urban Societies. Lanham, MD: Lexington Books, 2016. 272 pp.
Harrison, Mark. Contagion: How Commerce Has Spread Disease. New Haven, CT: Yale University Press, 2013. 400 pp.

\section{Neurology}

Bernat, James L. Ethical Issues in Neurology, $3^{\text {rd }}$ ed. Philadelphia: Lippincott Williams \& Wilkins, 2008. 544 pp.

Bernat, James L., and Richard Beresford, eds. Ethical and Legal Issues in Neurology. New York: Elsevier, 2013. 472 pp.

Fins, Joseph J. Rights Come to Mind: Brain Injury, Ethics, and the Struggle for Consciousness. New York: Cambridge University Press, 2015. 391 pp.

Glannon, Walter. Bioethics and the Brain. New York: Oxford University Press, 2007. 248 pp.

Machado, Calixto. Brain Death: A Reappraisal. New York: Springer, 2007. 223 pp.

\section{Neurosurgery}

Ammar, Ahmed, and Mark Bernstein, eds. Neurosurgical Ethics in Practice: Value-Based Medicine. New York: Springer, 2014. 286 pp.

\section{Organ Transplantation}

Caplan, Arthur L., James J. McCartney, and Daniel P. Reid, eds. Replacement Parts: The Ethics of Procuring and Replacing Organs in Humans. Washington, DC: Georgetown University Press, 2015. 360 pp.

Greenberg, Rebecca, Aviva Goldberg, and David Rodriquez-Arias, eds. Ethical Issues in Pediatric Organ Transplantation. New York: Springer, 2016. 340 pp.

Hamilton, David. A History of Organ Transplantation: Ancient Legends to Modern Practice. Pittsburgh, PA: The University of Pittsburgh Press, 2012. 560 pp.

Henderson, D. Scott. Death and Donation: Rethinking Brain Death as a 
Means for Procuring Transplantation Organs. Eugene, OR: Pickwick Publications, 2011. 212 pp.

Jensen, Steven J., ed. The Ethics of Organ Transplantation. Washington, DC: The Catholic University of America Press, 2011. 344 pp.

\section{Pediatrics}

Diekema, Douglas S., Mark R. Mercurio, and Mary B. Adam, eds. Clinical Ethics in Pediatrics: A Case-Based Textbook. New York: Cambridge University Press, 2011. 262 pp.

Di Pietro, Nina, and Judy Illes, eds. The Science and Ethics of Antipsychotic Use in Children. Waltham, MA: Academic Press, 2015. 228 pp.

Frankel, Lorry R., Amnon Goldworth, Mary V. Rorty, and William A. Silverman, eds. Ethical Dilemmas in Pediatrics: Cases and Commentaries. New York: Cambridge University Press, 2009. 316 pp.

Greenberg, Rebecca, Aviva Goldberg, and David Rodriquez-Arias, eds. Ethical Issues in Pediatric Organ Transplantation. New York: Springer, 2016. 340 pp.

Grossman, Miriam. You're Teaching My Child What?: A Physician Exposes the Lies of Sex Ed and How They Harm Your Child. Washington, DC: Regnery Publishing, Inc., 2009. 256 pp.

Miller, Geoffrey, ed. Pediatric Bioethics. New York: Cambridge University Press, 2009. 304 pp.

Mohrmann, Margaret E. Attending Children: A Doctor's Education. Washington, DC: Georgetown University Press, 2005. 208 pp.

\section{Surgery}

Benatar, David, ed. Cutting to the Core: Exploring the Ethics of Contested Surgeries. Lanham, MD: Rowman \& Littlefield Publishers, Inc., 2006. 246 pp.
Hakim, Nadey, Vassilios Papalois, and Miran Epstein, eds. Ethical and Legal Issues in Modern Surgery. Hackensack, NJ: World Scientific Publishing Company, 2015. 500 pp.

Jericho, Barbara G. Ethical Issues in Anesthesiology and Surgery. New York: Springer, 2015. 238 pp.

\section{Vaccines}

Conis, Elena. Vaccine Nation: America's Changing Relationship with Immunization. Chicago: The University of Chicago Press, 2015. 344 pp.

Largent, Mark A. Vaccine: The Debate in Modern America. Baltimore: The Johns Hopkins University Press, 2012. 232 pp.

\section{Mental Health}

\section{Counselors/Therapists}

Herlihy, Barbara, and Gerald Corey, eds. ACA Ethical Standards Casebook, $7^{\text {th }}$ ed. Alexandria, VA: American Counseling Association, 2015. 275 pp.

Remley, Theodore P., and Barbara P. Herlihy. Ethical, Legal, and Professional Issues in Counseling, $5^{\text {th }}$ ed. New York: Pearson, 2015. 528 pp.

\section{Mental Health Professionals}

Ashley, Benedict M. Healing for Freedom: A Christian Perspective on Personhood and Psychotherapy. Washington, DC: The Catholic University of America Press, 2013. 344 pp.

Bersoff, Donald N. Ethical Conflicts in Psychology, $4^{\text {th }}$ ed. Washington, DC: American Psychological Association, 2008. 608 pp.

Cessario, Romanus, Craig Steven Titus, and Paul C. Vitz, eds. Philosophical Virtues and Psychological Strengths. Manchester, NH: Sophia Institute Press, 2013. 336 pp. 
Fisher, Celia B. Decoding the Ethics Code: A Practical Guide for Psychologists, $3^{\text {rd }}$ ed. Thousand Oaks, CA: Sage Publications, Inc., 2012. $456 \mathrm{pp}$.

Goldstein, Alan M., Randy K. Otto, and Kirk Heilbrun. Ethics in Forensic Psychology Practice. Hoboken, NJ: Wiley, 2016. 350 pp.

Knapp, Samuel J., and Leon VandeCreek. Practical Ethics for Psychologists: A Positive Approach, $2^{\text {nd }}$ ed. Washington, DC:

American Psychological Association, 2012. 312 pp.

Koocher, Gerald P., and Patricia Keith-

Spiegel. Ethics in Psychology and the Mental Health Professions, $3^{\text {rd }}$ ed. New York: Oxford University Press, 2008. 672 pp.

\section{Psychiatry}

Bloch, Sidney, and Stephen A. Green, eds. Psychiatric Ethics, $4^{\text {th }}$ ed. New York: Oxford University Press, 2009. 552 pp.

Di Pietro, Nina, and Judy Illes, eds. The Science and Ethics of Antipsychotic Use in Children. Waltham, MA: Academic Press, 2015. 228 pp.

Glannon, Walter. Bioethics and the Brain.

New York: Oxford University Press, 2007. 248 pp.

\section{Medicine ANd Religion}

\section{Medicine and Religion}

Daunton-Fear, Andrew. Healing in the Early Church: The Church's Ministry of Healing and Exorcism from the First to the Fifth Century. Eugene, OR: Wipf \& Stock Publishers, 2009. 210 pp.

\section{Medicine and Spirituality}

Cobb, Mark, Christina M. Puchlaski, and Bruce Rumbold, eds. Oxford Textbook of
Spirituality in Healthcare. New York: Oxford University Press, 2012. 512 pp. Haynes, Jr., William F., and Geffrey B. Kelly. Is There a God in Health Care? Toward a New Spirituality of Medicine. New York: Routledge, 2006. 252 pp.

Koenig, Harold G. Spirituality in Patient Care: Why, How, When, and What, $3^{\text {rd }}$ ed. West Conshohocken, PA: Templeton Press, 2013. 352 pp.

Peteet, John R., and Michael N. D'Ambra, eds. The Soul of Medicine: Spiritual Perspectives and Clinical Practice. Baltimore: Johns Hopkins University Press, 2011. 272 pp.

\section{END OF LIFE}

\section{Art of Dying Well}

Dugdale, Lydia, ed. Dying in the Twenty-First Century: Toward a New Ethical Framework for the Art of Dying Well. Cambridge, MA: The Massachusetts Institute of Technology Press, 2015. 224 pp.

Gawande, Atul. Being Mortal: Medicine and What Matters in the End. New York: Metropolitan Books, 2014. 304 pp.

Gordon, Peggy Sturman. Psychosocial Interventions in End-of-Life Care: The Hope for a "Good Death". New York: Routledge, 2016. 208 pp.

Jones, David Albert. Approaching the End: $A$ Theological Exploration of Death and Dying. New York: Oxford University Press, 2007. 256 pp.

\section{Brain Death}

de Mattei, Roberto, and Paul A. Byrne, eds. Finis Vitae: Is "Brain Death" True Death? updated ed. Oregon, OH: Life Guardian Foundation, 2009. 380 pp. 
Glannon, Walter. Bioethics and the Brain. New York: Oxford University Press, 2007. 248 pp.

Henderson, D. Scott. Death and Donation: Rethinking Brain Death as a Means for Procuring Transplantation Organs. Eugene, OR: Pickwick Publications, 2011. 212 pp.

Machado, Calixto. Brain Death: A Reappraisal. New York: Springer, 2007. 223 pp.

\section{End of Life}

Bagheri, Alireza, ed. Medical Futility: $A$ Cross-National Study. London: Imperial College Press, 2013. 312 pp.

Broom, Alex. Dying: A Social Perspective on the End of Life. Burlington, VT: Ashgate Publishing Company, 2015. 186 pp.

DeCesare, Michael. Death on Demand: Jack Kevorkian and the Right-to-Die Movement. Lanham, MD: Rowman \& Littlefield, 2015. $246 \mathrm{pp}$.

Dowbiggin, Ian. A Merciful End: The Euthanasia Movement in Modern Amer- ica. New York: Oxford University Press, 2003, 272 pp.

Fins, Joseph J. A Palliative Ethic of Care: Clinical Wisdom at Life's End. Sudbury, MA: Jones \& Bartlett Learning, 2005. 281 pp.

Fleming, David A., and John C. Hagan III, eds. Care of the Dying Patient. Columbia, MO: University of Missouri Press, 2010. 170 pp.

Gawande, Atul. Being Mortal: Medicine and What Matters in the End. New York: Metropolitan Books, 2014. $304 \mathrm{pp}$.

Gomez, Jose H. A Will to Live: Clear Answers on End of Life Issues. Irving, TX: Basilica Press, 2006. 68 pp.

Jackson, Emily, and John Keown. Debating Euthanasia. Portland, OR: Hart Publishing, 2012. 200 pp.

Jones, David Albert. Approaching the End: $A$ Theological Exploration of Death and Dying. New York: Oxford University Press, 2007. 256 pp. 